\title{
$\mathrm{XVI}$. On the quantities of heat developed in the condensation of the vapour of water, and in that of alcohol
}

\section{Count Benjamin Rumford}

To cite this article: Count Benjamin Rumford (1814) XVI. On the quantities of heat developed in the condensation of the vapour of water, and in that of alcohol, Philosophical Magazine Series 1, 43:189, 64-69, DOI: 10.1080/14786441408637971

To link to this article: http://dx.doi.org/10.1080/14786441408637971

曲 Published online: 27 Jul 2009.

Submit your article to this journal $\pi$

Џll Article views: 2

Q View related articles $\sqsubset$ 
do not think it beneath the notice of your Joumal, I will propose to the sagacity of your readers to discover. I know that it is rather out of fashion to offer these sort of questions to the public, though it was very common in the beginning of the last century, and was, I believe, attended with much advantage to science, by producing a widely extended emulation: even the questions yearly proposed in The Ladies' Diary are, I am persuaded, very advantageous to the studious in mathematics.

The question I propose is this:

Of any cube number under a million give the figure of the unit, the two last figures, and the number of places, instantly and without any aid of writing to name its cube root. For example, let the cube 438976 be the number whose root is to be named. Given, the two first figurs 43 , the last figure 6 , the number of places six. The root is to be immediately named.

Should the ingenuity of some of your correspondents not find out the rery simple method of doing this, I will with great pleasure communicate it to you for insertion when required.

I do not pretend that there is much use in this, but it may be an object of curiosity to some of your numerous readers.

$$
\text { I am, sirs, your obedient servant, }
$$

H. C. ENGLefield.

To Messrs. Nickolson and Tilloch.

XVI. On the Quantities of Heat developed in the Condensation of the Irapour of Water, and in that of Alcohol. By BevJamin Count Rumford*.

\section{\$1. Of the Quantily of lleat develosed in the Condensation of the Vupour of IVater.}

Having flles the calorimeter and placed it on its stand, a current of vapour was introluced into the serpentine through a cork placed in the lower aperture of the serpentine. This cork having been perforated with a hole two lines in diameter, in the iirection of its axis, a small cork (two lines in diameter and two in height) was fitted into it, and four other holes about a line in diameter, pierced horizontally through the sides of the large cork at two lirises below it; upper extrenity, and communicating with the hole tro lines in diamer in the axis of this cork, afforded a passage to the vaponr, to almit of its entering by four small channels horizontaliy into the serpentine.

As the apertures of these small channels were higher than the level of thic flat botion of the serpentine, the water which re-

* This paper wis read befure the French Institute as a supplement to the Count's Inquiry into the Heat dereloped by Combustion. Vide Phil. Mag. vol xiii. p. 296.

sulted 
sulted from the condensation of this vapme, did not prevent tie vapour from continuing to flow through these passages.

This vapour came from a long-nerked matras; coutcining distilled water, which was put on a portable sore placed in a chimney at some distance from the calorimeter; and in order to stop all direct cominunication of heat between the stove and the calorimetar, the former was maked by plates, and the tube which conducted the vapour to the calorimeter was wall covered with flanncl.

The cold water which filled the calorimeter was of a lower temperature than that of the chamber by $6^{\circ}$ of Fahrenheit and when the thermoneter of the calorimeter annomced an augmentation of temperature by $12^{\circ}$ of Fahrenheit, an end was put to the experiment.

The water produced by the condensation of the vapour in the serpentine was carefully weighed; and from its quantity, as well as from the heat communicated to the calorimeter, the heat developed by the vapour in its condensation was dictermined.

As a small part of the heat communicated to the calorimeter proceeded from the cooling of the water condensed in the serpentine, after the vapour had been changed into water, an account was kept of this heat. It was supposed that the water at the moment of condensation was at the teinperature of $212^{\circ} \mathrm{F}$. being that of boling water; and it was determined by calculation, what part of the heat communicated to the calorimeter must have been orring to this boiling water.

In making this calculation, no account was taken of the difference in the capacity of water for heat, which depends on its temperature : this is but imperfecty known; and besides, the correction which would have been the result, could not hut have been very small.

The following are the details and results of two experiments made on the 21 st of January 1812.

\begin{tabular}{|c|c|c|c|c|c|c|}
\hline \multirow{2}{*}{ 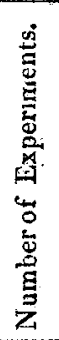 } & \multirow{2}{*}{ 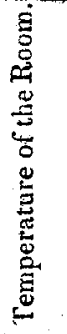 } & \multicolumn{3}{|c|}{$\begin{array}{l}\text { State of tne Calorineter (equal| } \\
\text { in capacity for Heat to } 2781 \\
\text { Grammes of Water.) }\end{array}$} & \multirow{2}{*}{ 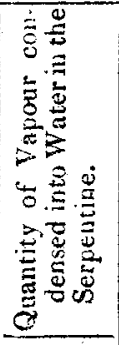 } & \multirow{2}{*}{ 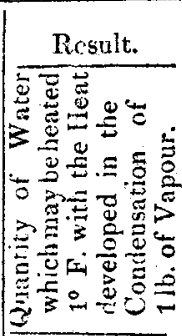 } \\
\hline & & 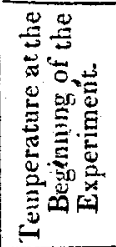 & 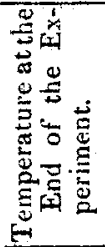 & 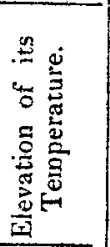 & & \\
\hline & $\begin{array}{l}61^{\circ} \\
62 \frac{1}{4} \mathrm{O}\end{array}$ & $\begin{array}{l}55^{\circ} \\
574^{\circ}\end{array}$ & $\begin{array}{l}67 \frac{I}{2} \\
67 \frac{\frac{1}{2}}{2}\end{array}$ & $\begin{array}{l}12 \frac{x}{1} \\
10 \frac{\pi}{2}\end{array}$ & & $\begin{array}{c}\text { lhs. } \\
1029 \cdot 3 \\
1052 \cdot 3 \\
\end{array}$ \\
\hline & & & & & esult & $1040 \cdot 8$ \\
\hline
\end{tabular}

Vol. 43. No. 189. Jan. 1814.

$\mathbf{E}$ 
By expresing the mean result of these two experiments in the ray employed by Mr. Watt and others, 1 shall say that 1040 degrees of heat (Fahrenheit) are liberated in the conilensation of steam, and that conseguently this very quantity of heat is emphoyed and rendered latent when the water, already at the temperature of briling water, is chaigged into steam.

The duration of each of these two experinints was from ten to eleven minntes, and I hal boiled the water some time in the matrass (to drive ont the air which it contained) before I directed the steam from it into the serpentine of the calorineter.

As the results of these experiments have been very uniform, and as they agree very well with the latter experiments made by Mr. Watt with a view to determine the same question, I have not thought it resectsary to repent them.

I hitre besites been very much occupied with the following brancin of nyy incunies.

\section{\$II. Of the Qucnitity of Heat developed in the Condensation of the Vupour of Alcohol.}

As chemints are not agred as to the state of the elements of the water which exist in alcohol, I thought that, by determining with precision the quantity of heat which is developed, we should be better able to form conjectures as to the state of the water, if it be at all times found in this inflammable liquid.

The results of the experiments which I made with alcohol are less regria: than those of the experiments made with water, as might have beful tepected; but they have nevertheless been sufticiently unifin to establish a fact, which will be regarded withotit donbt as very cmions and important.

As the rapour which is extricated from spirit of wine when boiler, rarios a little with the intensity of the fire wed in boiling it, I took are to note the time which was taken in every experiment, in ouder to be able to judge, by comparing the quantity of rajour ronderised, with the time enployed to form it, of the intensity of the heat employed to boil the liquid.

In the following table we shall see the details and results of five experiments made on the same day (Jannary 21, 1812) with alcohol of difierent degres: of strength. The eapacity of the calorimeter was always crpual to that of 2781 grammes of water, and the thermometer employed was that of Fahrenheit. 
'PAYL.

\begin{tabular}{|c|c|c|c|c|c|c|c|c|}
\hline \multirow{9}{*}{ 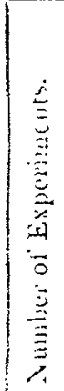 } & \multirow{9}{*}{ 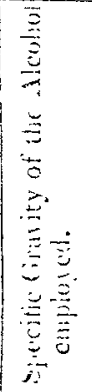 } & \multirow{9}{*}{ 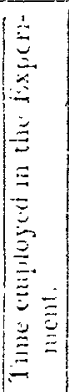 } & \multirow{9}{*}{ 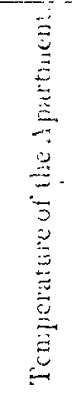 } & \multicolumn{3}{|c|}{$\begin{array}{l}\text { State of the Caluri } \\
\text { meter. }\end{array}$} & \multirow{2}{*}{ 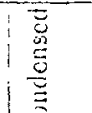 } & \multirow{2}{*}{$\frac{\text { Result. }}{\Xi 5}$} \\
\hline & & & & & 5 & & & \\
\hline & & & & $\stackrel{m}{m}$ & 栗 & $\cong$ & 8 & 45 \\
\hline & & & & $\stackrel{\varrho}{ٍ}$ & $\stackrel{3}{ت}$ & 5 & 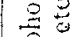 & 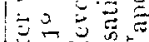 \\
\hline & & & & 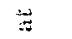 & 要 & $\cong$ & $\bar{\Xi} \cdot \vec{\Xi}$ & $\approx \sigma=$ \\
\hline & & & & 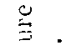 & $\frac{2}{3}$ & $\because$ & $+=$ & $=2-1=$ \\
\hline & & & & $\approx$ & تِّ & 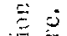 & 5 & $=\bar{z}$ \\
\hline & & & & 至 & 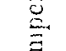 & 语 & 焉 & 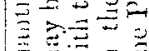 \\
\hline & & & & 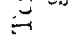 & $\stackrel{c}{\stackrel{c}{*}}$ & 3 & 8 & \\
\hline & & & $m i$ & & & & & \\
\hline 1 & 853.12 & 7 & $01^{\circ}$ & $514^{0}$ & 680 & $1.7^{\circ}$ & 0 & 45 \\
\hline 2 & $353+2$ & 5 & $\dot{0}$ & $56^{\circ}$ & $004^{\circ}$ & 10 & 5 & 47 \\
\hline 3 & 81714 & 8 & 60 & $55^{\frac{1}{2} 2^{\circ}}$ & $05 \frac{1}{2} 8$ & $10^{2}$ & 48 & \\
\hline 4 & 81703 & $4 \frac{x}{4}$ & 610 & $56^{\circ}$ & $66^{\frac{1}{2}} \frac{1}{2}$ & 105 & 56 & 479.92 \\
\hline 5 & 85342 & $6 \frac{5}{3}$ & $64^{0}$ & $57^{\circ}$ & $71 \frac{1}{2}^{\circ}$ & $11 \%^{\circ}$ & $71 \cdot 31$ & 49965 \\
\hline
\end{tabular}

On determining, by calculation, the quantity of water which may be heated one degree, by the heat developed in the combustion of me pound of this vapour, I took care to keep an account of the difference between the capacity of water for heat and that of alcohol, when I determined how much heat should have been comnumicated to the calorimeter by the alcohol, and produced by the condensation of the steam, by being cooled in the worm.

In order to prove the state of the elements of the water which exist in the steam of alcohol, it must be shown how much water these elements ought to form.

We shall select the experiment which was made with alcohol of the specific gravity of 81763 , and which sontained the least water. The quantity of stean condensed in this experiment was $56 \cdot 61$ grammes.

In 100 parts of this alcohol there were

91.79 parts of pure alcohol of Lowitz, and

8.21 parts of water.

Consequently there were in the 56.61 grammes of alcohol condensed in the calorineter,

51.962 grammes of alcohol of Lowitz, and

$4 \cdot 618$

of water.

Now, as M. de Saussure has shown that there are 47 parts of water in 100 parts of alcohol of Lowitz, there must have been $24 .+22$ grammes of water in the 51.962 gramnes of alcoliol of Lowitz, which were condensed in the calonimeter. 
Heat licereloped in Condensution of Fupour of Alcohol.

If to this quantity of water $(=21 \cdot 122$ grammes) we add the $4 \cdot 648$ grammes which werc found mixed with $51 \cdot 962$ grammes of alcohol of Lowitz, in order to compose the 56.61 grammes of alchol employed in the experiment, we shall lave $29 \cdot 07$ sramnes of water which ought to have existed, ready formed either in the common sitte of water, or in some other state, in the 36.61 granmes of alcohol condensed in the calorimeter.

Fut the condensation of 29.07 grammes of steam into liquid water onght to have of themselves furnished more heat than we had in the experiment in qurstion, in the condensation of these 29.07 grammes of elements of water, with 27.57 grammes of carbon and bydregcn, which concur, with these elements, in forming the stem of the aleohol which was condensed.

If we apply a similar calculation to the results of the experiments made with alcoliol which contained more water, the result of the ineniry will be still more strilizg.

In the caperiment No.5. the alcohol employed was of the speciac gicity of 3.9244 : conscquently 100 parts of this alcohol were composed of 77.88 parts of alcohol of Lowitz, and $22 \cdot 12$ water.

And in the experintent 71.82 grammes of vapour of alcohel wire endencel.

There were theretore in these $71 \cdot 1$ grommes of condensed alcohol,

55. 889 grammes of alcoliol of Lovitz, and

$15 \cdot 62.2$ grammes of water.

In the 55.9858 grammes of alcohol of Lowitz there were 20.102 grammes of water, according to the analysis of $\mathrm{M}$. de Saussure; and this last quantity of vater ( $=26 \cdot 012$ grammes) alded to the quantity found above, viz. 15.622 grammes, makes 41.727 grammes of water which ought to have existed, either as stenz or othervoe, fin the $71 \cdot 31$ grames of alcoholic vapour condenced in the eubrimeter, in the experiment in question.

In orlor to simplify ov culculation, and to render our com-

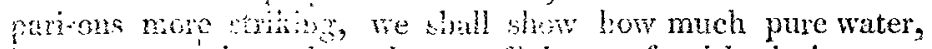

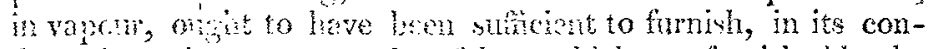

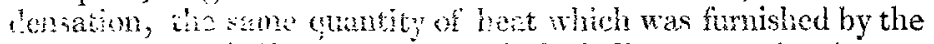
condenention of 71 . 1 grames of alcoholie vapour, in the experiment in mestion.

In this experinent the temperature of the calorimeter was

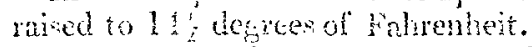

In the scond experinent, male with the steam of pure water, the temperature of the newse colonineter was raised $10 \frac{2}{2}$ degrees of Fatrenheit, with the heat developed in the condensation of $2 \frac{1}{2} \cdot 4$ gramnes of this rapour.

Conse- 
Consequently the temperatne of the calcrimeter must have been elevated to $1 \frac{1}{2}$ cherrees of Fitrenkeit, with the leat which must have been daveloped in the condensation of 333.695 grammes of stcan from pure water.

Now as the hyorngen and thorygen forming the elements of 41.727 gramme; of water, wibl are found to form constituent parts of the $71 \cdot 31$ grammes of vapour of alcobol condensed in the experiment in gnetion, only firmished in their condensation the same quantity of heat as $33^{\circ} 695$ grammes of steam of pure water should have furnished, it is eleariy proved, in my opinion, that these elements are not so united as to form water, so long as they coneur in the formation of alcohol.

I have discovered that the vapour of sulphuric ether furnishes about one half less of heat in its condensation than that of alcohol, and consequently one fourth only of what is furnished by the steam of water of equal weight; but having been interrupted by an accident in the course of my experiments with ether, I am desirous of fnishing them before I publish the results.*

\section{Proceedings of Learned Societies.}

ROYAL SOCIETY.

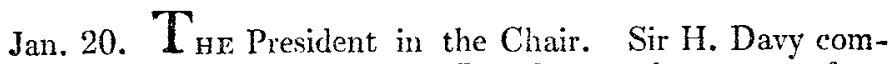
municated, in a letter to the President, a long paper from Paris, on a new gas discovered in that city by $M$. Courtois, a manufacturer of saltpetre. It appears that this gas was discovered above two years ago; but such is the deplorable state of scientific men in France, that no account of it was published till the arrival of our English philosopher there. M. Courtois commuilicated his discovery to Clement and Desormes, who made some experiments with the gas, and latterly M. Gay Lusac has devoted his attention to an, examination of its history and properties. Mean time Sir Humphry has made a great number of experiments on it, and would have made several more had he not wanted the necessary apparatus in Paris. M. Courtois was led to the discovery ky observing how rapidly his metal pots were corroded in preparing the different kinds of sea-weed, which he used for making carbonate of soda. When the soda is extracted from the sea-weed, the new gas is easily disengaged; by pouring strong sulphuric acid on the residum, at

* In a sulsequent number we shall give the learned author"s "Inquiries in to the Capanty for lleat, or the calurlic Power of various Liquids," as being connected with the furegang menoir-Eprons. 